Historic, Archive Document

Do not assume content reflects current scientific knowledge, policies, or practices. 

United States

Agriculture

Forest

Service

Forest Pest

Management

Methods

Application

Group

Fort Collins

Colorado 80524

(4ivs

\section{EFFICACY OF BACILLUS THURINGIENSIS ON WESTERN SPRUCE BUDWORM RELATIVE TO DEPOSIT DENSITY AND FOLIAR DEVELOPMENT}

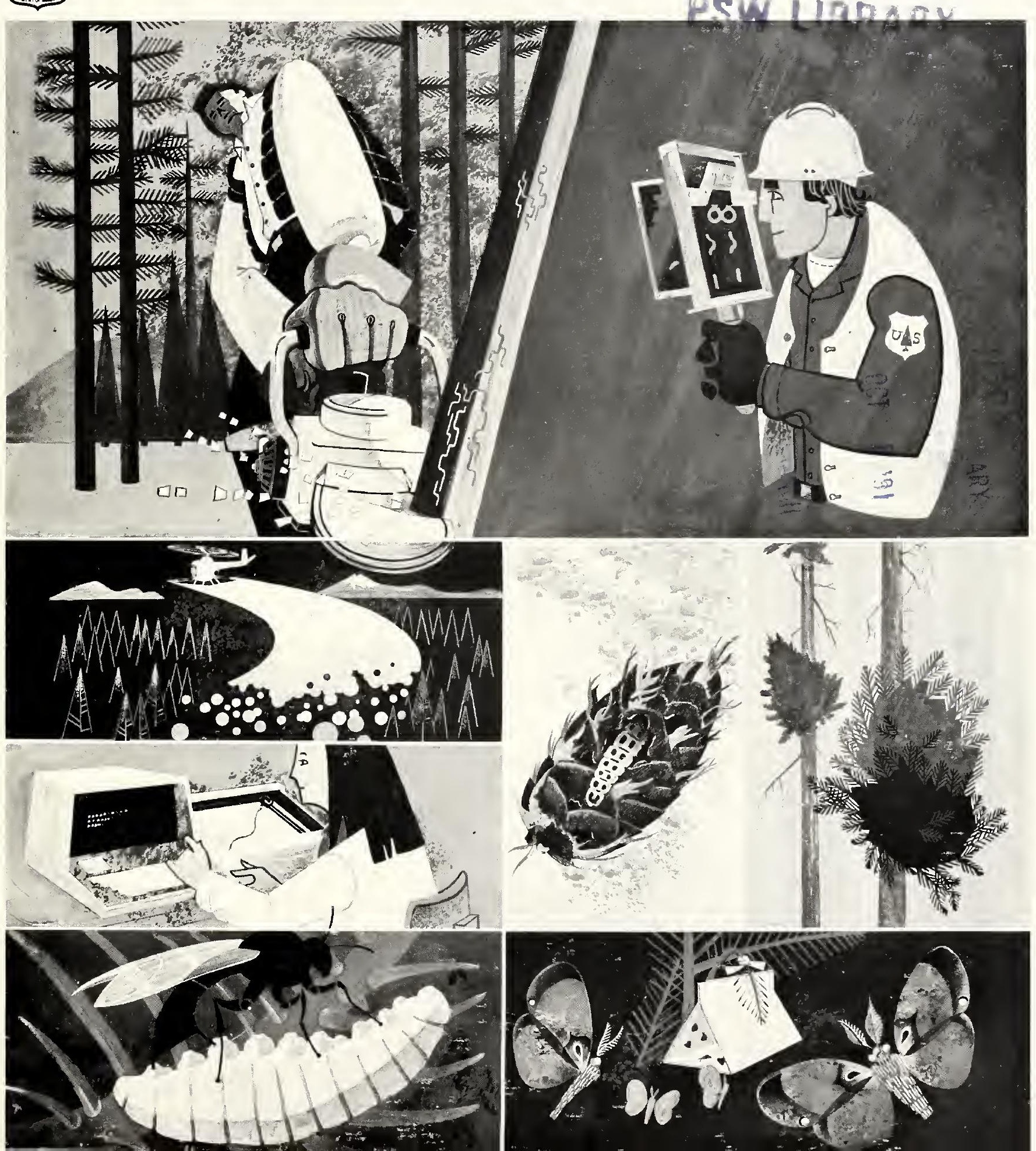



EFFICACY OF BACILLUS THUR INGIENS IS ON WESTERN SPRUCE BUDWORM RELATIVE TO DEPOSIT DENSITY AND FOLIAR DEVELOPMENT

by

M.A. Marsden 1/, D.B. Twardus $2 /$, and W.M. Ciesla $3 /$

\section{ABSTRACT}

Two formulations of the microbial insecticide, Bacizlus thuringiensis, were evaluated in a pilot control project in central Montana in 1981 against western spruce budworm. The formulations were Thuricide 16B and Dipel 4LI/. Measurements were taken describing spray deposits and stage of bud development as well as budworm density. Using linear regression, budworm mortality was related to variables describing the spray density and bud development.

\section{INTRODUCT ION}

Efficacy of an aerially applied insecticide is governed by a number of factors. These include the toxicity to the target insect and the quality of the application. In the case of an insecticide which must be ingested in order to be effective, such as the bacterium, Bacillus thuringiensis Berliner (B.t.), development of the host foliage may also influence field efficacy. For example, if this material is applied before bud burst to larvae which feed on new growth of coniferous foliage, such as the western spruce budworm, Choristoneura occidentalis Freeman, efficacy could be reduced.

Field procedures for measuring quality and consistency of aerial application of insecticides in terms of deposit recovery have been developed and are described in considerable detail (Barry et al. 1978). However, correlation between deposit (mass or droplets $/ \mathrm{cm}^{2}$ ) and mortality has consistently been low (Flavell et al. 1978; Flavell et al. 1977; Barry et al. 1978 ).

1/Biometrician, USDA Forest Service, Forest Pest Management, Methods Application Group, Fort Collins, CO 80526.

$2 /$ Entomologist, (CANUSA), FPM, Region 6, Portland, OR 97208.

3/ Entomologist, USDA Forest Service, Forest Pest Management, Methods Application Group, Fort Collins, CO 80526

4 /Mention of commercial products is for convenience only and does not imply endorsement by USDA. 
Similarly, work by Twardus (1982) failed to establish a relationship between bud development, instar development, and larval survival following treatment of $\mathrm{C}$. occidentalis infestations with B.t. He suggests that some of the variation in insect mortality may be the result of insufficient spray deposit.

This paper reports on the relationship of both spray deposit and foliage development on efficacy of B.t. against western spruce budworm.

METHODS

PILOT PROJECT DESCRIPTION

In 1981 a pilot control project was conducted on the Deerlodge National Forest in central Montana against western spruce budworm (Stipe et al. 1983). Two commercial formulations of B.t., Bacillus thuringiensis Berliner, Thuricide 16B and Dipel 4L, were applied at 8 bilion international units (BIU) per acre (19.8 BIU per hectare) to areas of budworm infestation. Spray was applied with two Ayers Turbo Thrush aircraft equipped with full jet $1 / 8$ $66 \mathrm{~A} 8 \mathrm{~W}$ nozzles calibrated to apply one gallon of tank mix per acre ( 9.35 liters per hectare).

The pilot project design included nine blocks ranging from 2,000-4,200 acres in size. Treatments were randomly assigned. Three blocks were treated with Dipel 4L, three with Thuricide 16B, and three were left as untreated checks.

Budworm mortality at 21 days post spray was 48 percent for Dipel, 62 percent for Thuricide, and 26 percent for control. These are average mortality rates based on sampling larvae density on two occasions from 25 sample points per treatment block.

FIELD DATA COLLECTION

Each sample point contained a cluster of three trees. Cluster locations were at least two chains ( 40 meters) from one another, block boundaries, or main roads.

Sample trees were open-grown Douglas-fir, 35 to 60 feet ( 11 to 18 meters) tall with full crowns. Defoliation from previous years was generally below 25 percent. Four $45 \mathrm{~cm}$ branch samples were taken from each tree for each sample period. The number of larvae per hundred buds was calculated for each cluster.

Spray deposit evaluation was based on amount of spray material deposited on Kromekote cards. Rhodamine Extra $S$ dye was added to each tank mix at the rate of one pound per 100 gallons (120 grams per 100 liters). Four plastic card holders with Kromekote cards were located around each sample tree, one at each cardinal compass point (N, S, E, W) just beneath the drip line. Wooden stakes were used to support samplers approximately six inches $(15 \mathrm{~cm})$ above the ground. Where stakes could not be used, debris was cleared and the sampler was placed on the ground. 
Samplers were placed in position at each cluster during the predawn hours before spraying began. Cards were allowed to dry for approximately one-half hour before retrieval (Fig. 1). Because the Thuricide treated cards had an extended drying time, these cards were placed in special holders designed to prevent adjacent surfaces from touching and the spray droplets smearing.

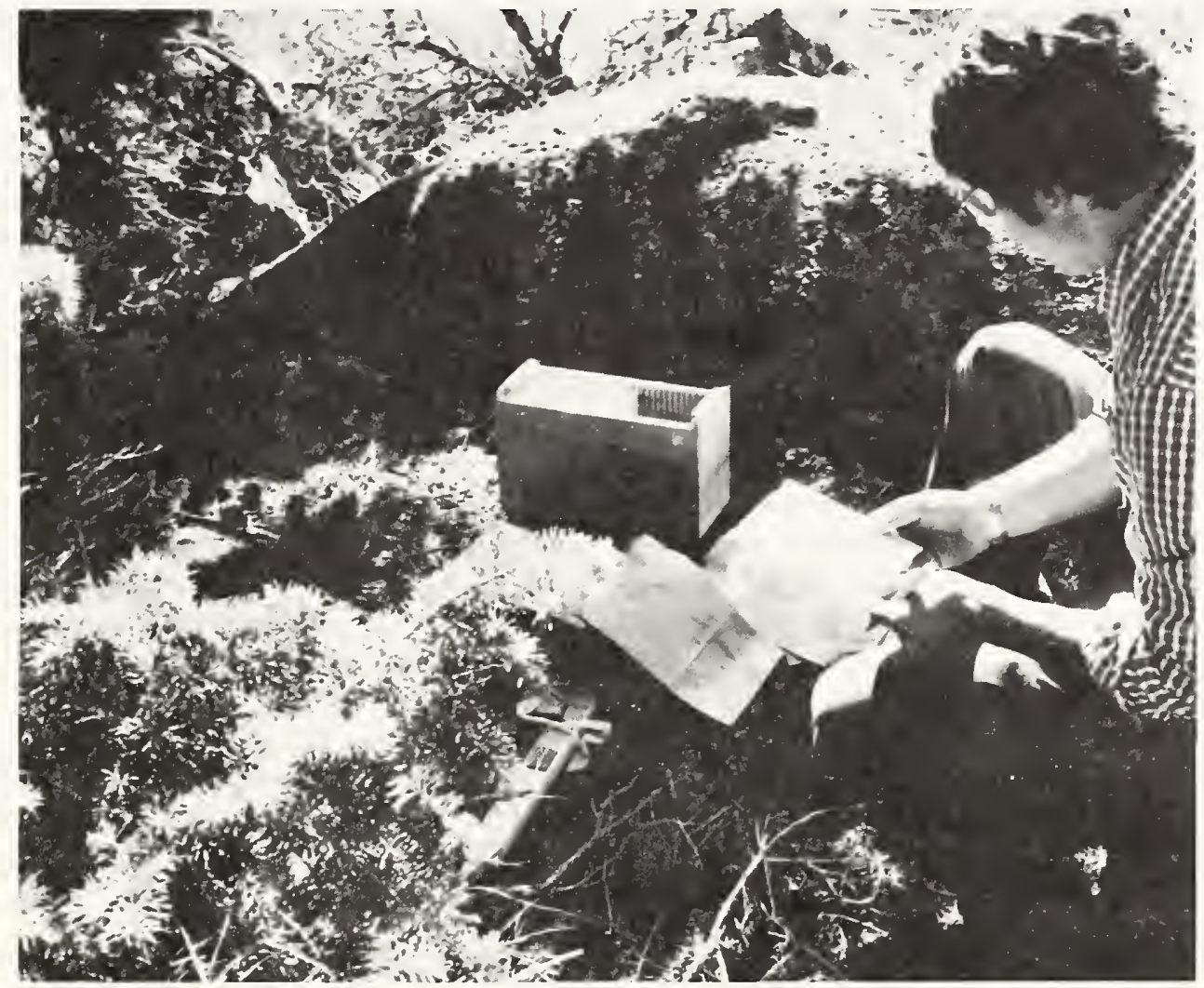

Figure 1 - Collecting spray deposit cards following application of Bacillus thuringiensis. Deerlodge National Forest, Montana, 1981

Spray deposit cards were analyzed in Davis, California, using a Quantimet image analyzer (Young et al. 1977). Data on droplet density (drops $/ \mathrm{cm}^{2}$ ), mass $\left(\mathrm{mg} / \mathrm{cm}^{2}\right)$, and droplet size (vmd) were obtained.

Data on bud development reported earlier by Twardus (1982) was used in this analysis. At one half of the sample points, bud development was measured. Ratios of fully expanded buds, none to partially expanded, and nonopen buds were recorded at 73 of the 150 sample points in the blocks treated with B.t. Nonopen buds provide a small target for the spray droplets. They also provide shelter for third instar larvae which mine these buds. 
ANALYS IS

Linear regression was used to relate 21 day post spray mortality to variables describing spray deposit and stage of bud development.

Variation in insect mortality from one sample point to another can be due to: formulations of B.t.; effective amount of B.t. applied to the sample point; variation in response among insects; and sampling variation of insects.

The two formulations of B.t. vary chiefly in that one contains a water carrier, the other contains both water and oil as a carrier. The volume of B.t. applied can be measured indirectly as drop density, mass and median drop size. Variation in insect response may be expressed by stage of insect development and insect density. For example, larvae mining a nonopen bud are protected from the spray. They may remain in this condition until the critical period for consuming a lethal dose of viable B.t. has passed (Varty and Godin, 1983). Sampling variation is due to sampling on two occasions to calculate a ratio (Walton and DeMars, 1973).

The basic variables used in the analysis of larval mortality are summarized in Table 1. The sampling variation associated with the mortality estimate is not shown however. Approximation to the sampling error for mortality can be calculated using the data from the individual trees at a cluster point.

Mortality ratio at a sample cluster is estimated as:

where $\bar{y}$ is the mean larval density in the post treatment sampling and $\bar{x}$ is the mean larval density in pretreatment sampling. The means ( $\bar{y}, \bar{x}$ ) are based on the samples from three trees in the cluster.

The variance of can be approxjmated by

$$
v(\hat{R})=\frac{1}{\bar{x}^{2}}\left(V[y]+\hat{R}^{2} v[x]-2 R \operatorname{cov}[x, y]\right) \text {. }
$$

Table 1: Mean, Standard Deviation and Range of Variables Used in Analysis of Larval Mortality

$\begin{array}{lcccc}\begin{array}{l}\text { Drop Density } \\ \left(\text { drops } / \mathrm{cm}^{2}\right)\end{array} & 11.70 & 7.19 & 1.61 \text { to } & 32.98 \\ \begin{array}{l}\text { Mass } \\ \left(\text { grams } / \mathrm{cm}^{2}\right)\end{array} & 0.19 & 0.15 & 0.01 \text { to } & 0.65 \\ \begin{array}{l}\text { VMD } \\ \text { (volume medium } \\ \text { diameter um) }\end{array} & 207.86 & 58.72 & 77.60 \text { to } 375.50 \\ \begin{array}{l}\text { Nonopen Bud Ratio } \\ \text { Partially Open Bud }\end{array} & 0.06 & 0.09 & 0.00 \text { to } & 0.45 \\ \begin{array}{l}\text { Ratio } \\ \text { Larval Mortality }\end{array} & 0.23 & 0.19 & 0.03 \text { to } & 0.81 \\ & 0.61 & 0.22 & 0.01 \text { to } & 0.96\end{array}$


The use of regression assumes that the dependent variable has a constant variance. When the dependent variable is a ratio the variance is often a simple function of the means and can be transformed to achieve constant variance. In this case the variance of the mortality ratio is due chiefly to sampling on two occasions. Linear regression was used to model the mortality ratio per cluster untransformed, as a function of the spray deposit and stage of bud development. Were we to use the block means as observations the inverse of the estimated variance could be used as a weighting function to achieve constant variance.

The variables, drops $/ \mathrm{cm}^{2}$ and mass $\mathrm{mg} / \mathrm{cm}^{2}$, can be used to model larval mortality as a function of B.t. deposit. Transformations and interactions of these variables were used to evaluate alternative models. When the basic mechanism of a system is incomplete (we have not identified all items that effect our observed mortality rate), the system can be represented or described by several models.

\section{RESULTS AND DISCUSSION}

The pooling of the data from each of the two B.t. formulations is accepting the hypothesis that these formulations are equal. Although under controlled laboratory conditions differences may exist, in this pilot project such differences were not observed. The difference in mortality found in areas treated by these two formulations could be attributed to treatment quality and phenological development.

A test for an effect of treatment formulation, given the treatment quality and vegetation condition is presented in Table 2. The formulation was represented by a dummy variable which had the value of 1.0 for Dipel and -1.0 for Thuricide. This variable was not significant at the 0.10 level.

After comparing several models using statistical criteria (small standard error of predicted, significant coefficients) and plotting the response surfaces, the following model was adopted:

$$
\begin{aligned}
\mathrm{Y}= & 0.51198+0.00760(\mathrm{D})+0.30672(\mathrm{M})-0.70710(\mathrm{NB}), \\
& \text { with } \mathrm{R}^{2}=.24, \text { standard error }(\mathrm{y})=.20,
\end{aligned}
$$

Where: $Y=$ Larvae mortality at 21 -days post treatment

$$
\begin{aligned}
\mathrm{D} & =\mathrm{drops} / \mathrm{cm}^{2} \\
\mathrm{M} & =\text { mass in } \mathrm{Mg} / \mathrm{cm}^{2} \text { of } \mathrm{B} . \mathrm{t} . \\
\mathrm{NB} & =\text { Ratio of non-open buds }
\end{aligned}
$$

This model is only a predictive one; however, we believe it reproduces the main features of the behavior of the mortality rate under the conditions of this project. Statistical attributes of the model are shown in Table 3. 
Table 2: Regression Analysis of Western Spruce Budworm Mortality with B.t. Formulation as Variable

Multiple Correlation, $\mathrm{R}^{2}=0.2598$

Standard Error of Regression, $\mathrm{SE}(\mathrm{Y})=0.1999$

Analysis of Variance

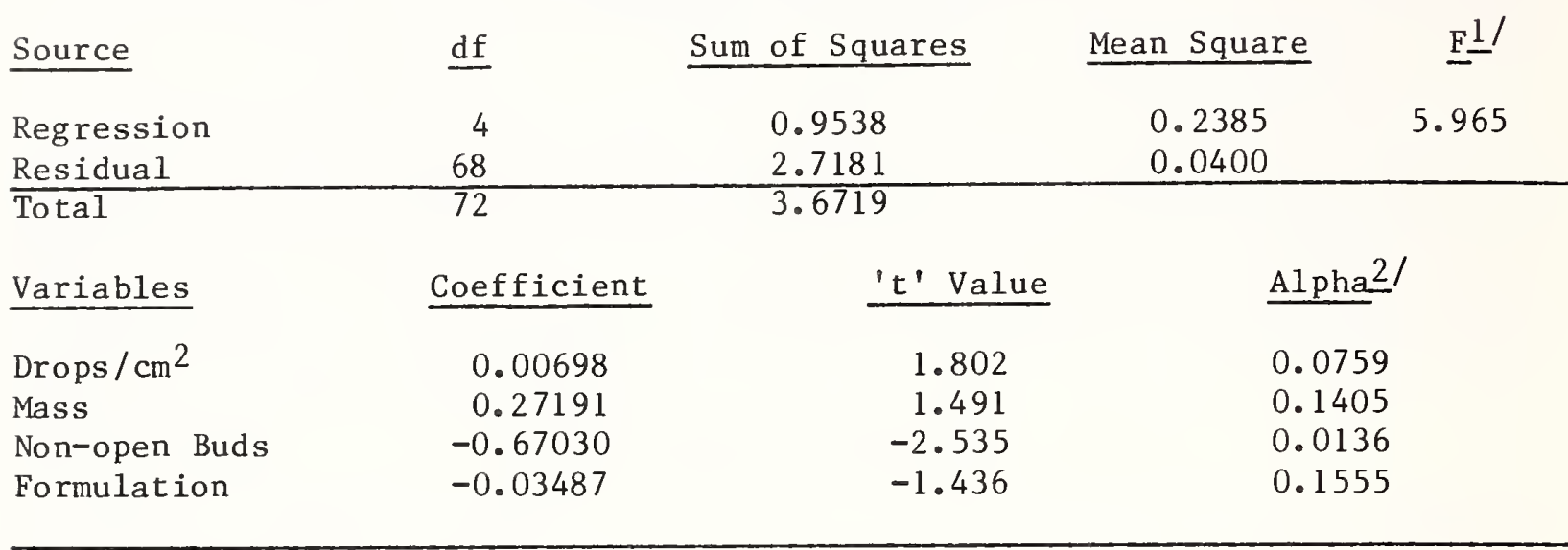

Table 3: Regression Analysis of Western Spruce Budworm in $\mathrm{R}-1$

Thuricide 16B - Dipe1 4L Pilot Project

Multiple Correlation Coefficient, $R^{2}=0.2373$

Standard Error of Regression, $\mathrm{SE}(\mathrm{Y})=0.2015$

Analysis of Variance

\begin{tabular}{lcccc} 
Source & df & Sum of Squares & Mean Square & F \\
Regression & 3 & 0.8714 & 0.2905 & 7.156 \\
Residual & 69 & 2.8006 & 0.0406 & \\
\hline Total & 72 & 3.6720 &
\end{tabular}

\begin{tabular}{lrrr} 
Variable & Coefficient & 't'Value & Alpha \\
\cline { 2 - 3 } Drops $/ \mathrm{cm}^{2}$ & 0.00760 & 1.959 & 0.0541 \\
Mass & 0.30672 & 1.684 & 0.0966 \\
Non-open & -0.70710 & -2.166 & 0.0095
\end{tabular}

Buds

1/ $F=4.08$ with 3 and 70 degrees of freed om is significant at Alpha $\leq 0.01$.

$2 / \mathrm{A} 1$ pha $=1$ evel of significance for student's ' $t$ ' test, for coefficient equal to zero. 
The correlation between mass in $\mathrm{mg} / \mathrm{cm}^{2}$ and $\mathrm{drops} / \mathrm{cm}^{2}$ is a physical design problem (Smirnoff and Juneau, 1982). Neither few drops of large mass nor many drops of small mass were intended or observed in the project. Plots of mass and drop densities are shown in Figures 2 and 3 . Several combinations of variables and transformations of variables appeared to be of equal utility in modeling mortality due to this correlation.

Sampling variation in measuring mortality is inherently large. In field studies where mortality is obtained from sampling on two occasions both bias and large sampling errors are found (Walton and Lewis, 1982; Walton and DeMars, 1973). This introduces an element of "pure error" to the regression analysis (Draper and Smith, 1966). Modest values of $\mathrm{R}^{2}$ are expected under these conditions because the model should not be expected to explain sampling variation. Since this is a pilot project, several observations with identical sets of values for the independent variables are not found. The sample frequency by class intervals for mass and drop density is shown in Table 4.

In Table 5, the predicted mortality rates are given for combinations of mass $\left(\mathrm{mg} / \mathrm{cm}^{2}\right)$ and drops $/ \mathrm{cm}^{2}$ with the ratio of non-open buds set to 0.06 . In Table 6 the ratio of non-open buds is set to 0.45 . To calculate other conditions, the regression equation on Page 5 should be used.

The area of the table for which some observations exist is presented in Table 4. Values are computed to three decimal places for cells with sample data and are computed to two decimal places for cells without sample data. Only predictions thought to be realistic are included in the table. Unfilled cells represent conditions where the model does not give realistic values in the opinion of the authors.

Table 4: Sample Frequency by Class Intervals for Mass and Drop Densities B.t. Pilot Project, Deerlodge National Forest, Montana 1981

\begin{tabular}{|c|c|c|c|c|c|c|c|c|c|}
\hline Drops $/ \mathrm{cm}^{2}$ & 1.6 & 2.0 & 5.0 & 10.0 & 15.0 & 20.0 & 25.0 & 30.0 & 33.0 \\
\hline $\begin{array}{l}\text { Mass } \\
\mathrm{Mg} / \mathrm{cm}^{2} \\
0.01\end{array}$ & 2 & 4 & 2 & & & & & & \\
\hline 0.05 & & & 6 & 3 & & & & & \\
\hline 0.1 & & & 2 & 11 & 4 & & l & & \\
\hline 0.2 & & & 5 & 6 & 2 & 4 & & & \\
\hline 0.3 & & & & 4 & 3 & & $\mathrm{l}$ & l & \\
\hline 0.4 & & & & & 3 & 3 & & & 2 \\
\hline 0.5 & & & & & & & & & \\
\hline 0.6 & & & & & 1 & & & 1 & \\
\hline $0.65+$ & & & & 2 & & & & & \\
\hline
\end{tabular}




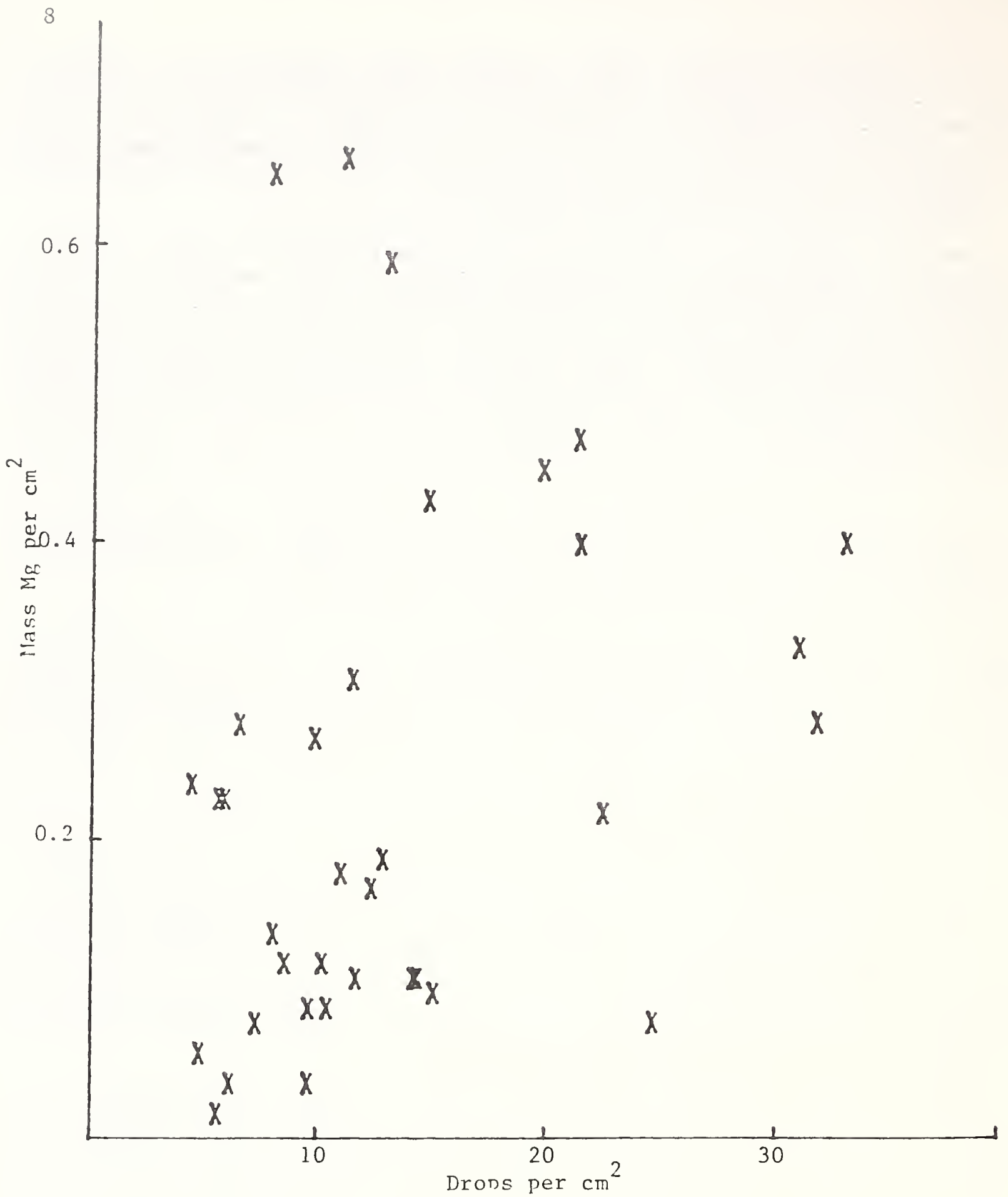

Figure 2 - Relationship of droplet density to mass, Thuricide 16B treated sample points, western spruce budworm pilot project, Deerlodge National Forest, Montana, 1981. 


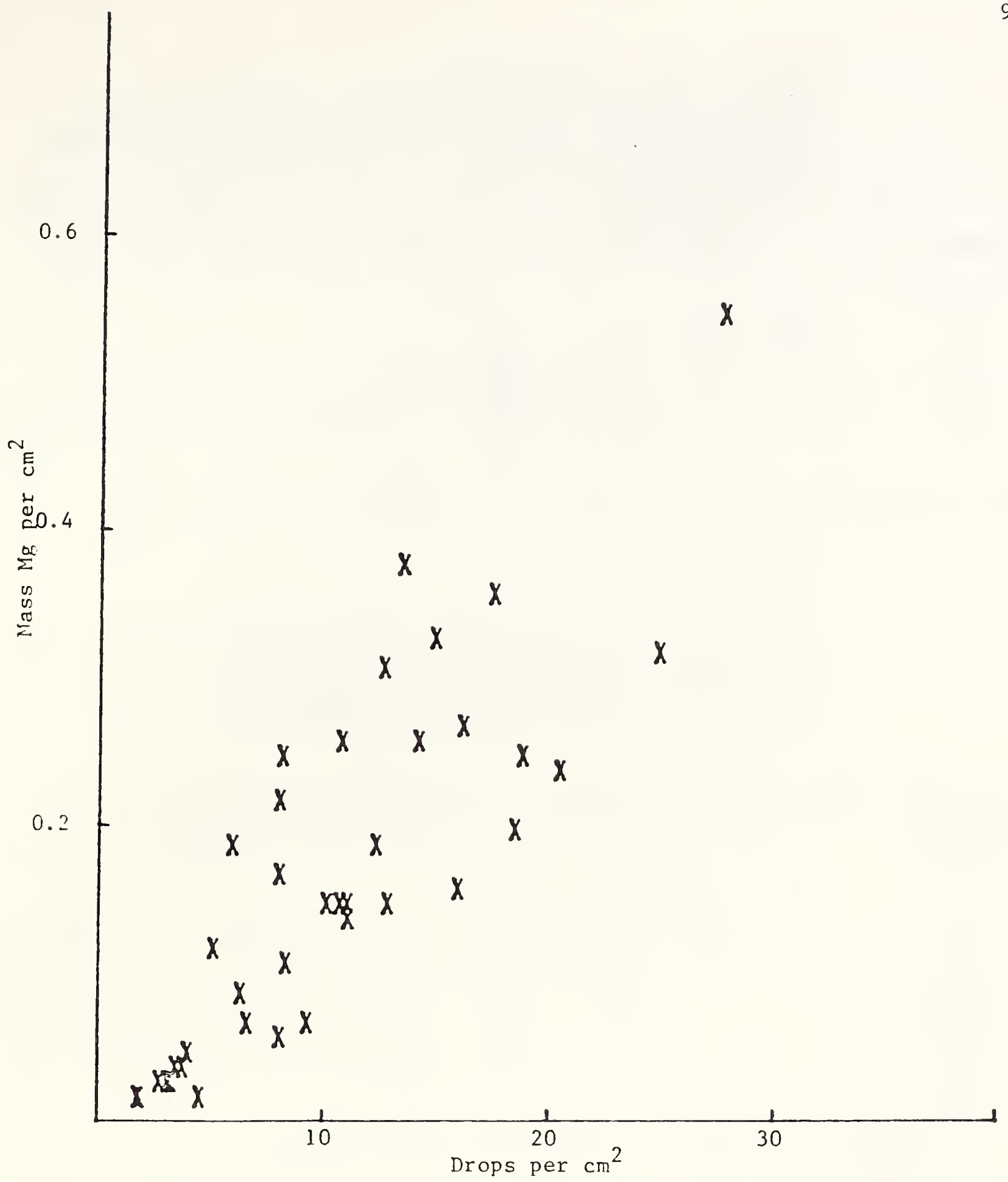

Figure 3 - Relationship of droplet density to mass, Dipe1 4L treated sample points, western spruce budworm pilot project, Deerlodge National Forest, Montana, 1981. 
Table 5: Predicted Mortality for Western Spruce Budworm 21 Days Following Treatment With B.t. (Thuricide 16B and Dipe1 4L), Non-open Bud Ratio is 0.06, Pilot Project Average, Deerlodge National Forest, Montana, 1981

\begin{tabular}{l|l|l|l|l|l|l|l|l|l}
\hline Drops $/ \mathrm{cm}^{2}$ & 1.0 & 2.0 & 5.0 & 10.0 & 15.0 & 20.0 & 25.0 & 30.0 & 35.0 \\
\hline
\end{tabular}

Mass $/ \mathrm{cm}^{2}$

\begin{tabular}{|c|c|c|c|c|c|c|c|c|c|}
\hline 0.01 & $0.4801 /$ & 0.488 & 0.511 & 0.549 & & & & & \\
\hline 0.05 & $0.49 \underline{2}$ & 0.50 & 0.523 & 0.561 & & & & & \\
\hline 0.10 & & 0.51 & 0.538 & 0.576 & 0.614 & 0.65 & 0.690 & 0.73 & 0.77 \\
\hline 0.20 & & & 0.569 & 0.607 & 0.645 & 0.683 & 0.72 & 0.76 & 0.80 \\
\hline 0.30 & & & 0.50 & 0.637 & 0.676 & 0.71 & 0.752 & 0.790 & 0.83 \\
\hline 0.40 & & & 0.63 & 0.67 & 0.706 & 0.744 & 0.78 & 0.82 & 0.858 \\
\hline 0.50 & & & 0.66 & 0.699 & 0.737 & 0.78 & 0.81 & 0.851 & 0.89 \\
\hline
\end{tabular}

Table 6: Predicted Mortality for Western Spruce Budworm 21 Days Following Treatment with B.t. (Thuricide 16B and Dipel 4L), Non-open Bud Ratio is 0.45, Deerlodge National Forest, Montana, 1981

\begin{tabular}{l|l|l|l|l|l|l|l|l|l}
\hline Drops $/ \mathrm{cm}^{2}$ & 1.0 & 2.0 & 5.0 & 10.0 & 15.0 & 20.0 & 25.0 & 30.0 & 35.0 \\
\hline
\end{tabular}

Mass $/ \mathrm{cm}^{2}$

$\begin{array}{llllllllll}.01 & 0.204 & 0.212 & 0.235 & 0.273 & & & & & \\ .05 & 0.22 & 0.22 & 0.247 & 0.285 & & & & & \\ 0.10 & & 0.24 & 0.262 & 0.300 & 0.338 & 0.38 & 0.414 & 0.45 & 0.49 \\ 0.20 & & & 0.293 & 0.331 & 0.369 & 0.407 & 0.44 & 0.48 & 0.52 \\ 0.30 & & & 0.32 & 0.362 & 0.400 & 0.44 & 0.476 & 0.514 & 0.55 \\ 0.40 & & & 0.35 & 0.39 & 0.430 & 0.468 & 0.51 & 0.54 & 0.582 \\ 0.50 & & & 0.38 & 0.423 & 0.461 & 0.50 & 0.54 & 0.575 & 0.61\end{array}$

1/Table values, $Y$, are based on the following equation:

$\mathrm{Y}=0.51198-0.7071$ (Non-open bud ratio) $+0.30672\left(\mathrm{Mass} / \mathrm{cm}^{2}\right.$ ) +0.0076 (Drops $/ \mathrm{cm}^{2}$ ).

2/Values calculated to two decimal places only are extrapolations to conditions without data. 
CONCLUS IONS

No difference between Thuricide $16 \mathrm{~B}$ and Dipel $4 \mathrm{~L}$ was detected in terms of western spruce budworm mortality. Differences in efficacy observed in the project can be related to spray deposit and the stage of bud development. Without accounting for the stage of bud development, the association of efficacy with spray deposit measurements was inconsistent.

Table 5 should be used to judge the spray deposit needed to achieve a required mortality.

Due to variation encountered in field projects it is difficult to build a regression model from such data. The expected value of the standard error of regression includes the error in measuring the mortality rate for a sample point.

If this variance is large, low values for $\mathrm{R}^{2}$ would occur even when the model expressed the true relationship of the spray quality and phenological development on larvae mortality.

Sampling variance has several sources. The mortality rate is based on two samples taken 21 days apart. The samples are destructive so one is not observing the number of survivors of a sample of $n$ larvae, but the difference between two density estimates. The sampling variance will have a component associated with the distribution of the larvae between sample dates, among trees within a sample point, and between sample branches on a tree.

Table 5 is the best reference to the relationship of spray deposit to mortality. As the number of drops per $\mathrm{cm}^{2}$ increase, mortality increases. The rate of increase changes with the mass of $B . t$. recovered. Phenological development of the vegetation also effects the mortality rate.

The 21 day observation may not be the best criteria for evaluation of a biological agent such as B.t. Some delayed reactions may produce an effective higher mortality rate. Larvae consuming non-lethal doses of B.t. (as measured at 21 days) may still not become healthy adults capable of mating and reproduction (Stipe et al. 1983). It is important that B.t. be consumed as a viable agent (spores and crystals). Since B.t. is viable for only a few days, the application of the mass into many small drops should increase the chance that the larvae will consume some viable B.t. Treatment following bud burst becomes important for the same reason. This increases the amount of B.t. intercepted by the insect's primary food source and leads to a higher chance that the larvae consumes viable B.t.

\section{ACKNOWLEDGMENTS}

The authors would like to thank Jack Barry, FPM/WO, Davis, CA; Larry Stipe, CFPM/R-1, Missoula, MT; Jim Colbert, CANUSA-W, Portland, OR; and Joyce Schlieter, INT, Missoula, MT, for the constructive reviews and assistance. 


\section{REFERENCES}

Barry, J.W., R.B. Ekblad, G.P. Marken and G.C. Trostle (Compilers) 1978. Methods for sampling and assessing deposits of insecticidal sprays over forests. USDA Tech. Bulletin 1596, 162 pp.

Draper, N.R. and H. Smith. Applied regression analysis, 1966. John Wiley \& Sons, Inc. $407 \mathrm{pp}$.

Flavell, T.H., S. Tunnock, J.W. Barry, R.B. Ekblad and W.M. Ciesla. 1978. Western spruce budworm, a pilot control project with carbaryl and trichlorfon - 1975. USDA Forest Service, State and Private Forestry, Northern Region, Missoula, MT, Rpt. No. 78-5.

Flavel1, T.H., S. Tunnock and H.E. Meyer. 1979. A pilot project evaluating trichlorfon and acephate for managing the western spruce budworm, Choristoneura occidentalis Freeman. Helena National Forest, MT. USDA Forest Service Forest Insect and Disease Management Northern Region, Missoula, MT, Rpt. No. 77-16, 49 pp.

Smirnoff, W.A. and A. Juneau. Physical analysis of the dispersion of Bacillus Thuringiensis against spruce budworm. LAU-X-55, 1982. 18 pp. Laurentian Forest Research Centre, Canadian Forest Service.

Stipe, L.E., C.G. Niwa, K.E. Gibson, H.E. Meyer, and B.G. Eder. 1983. B.t. pilot project against western spruce budworm in central Montana, 1981. Rpt. 83-4 R-1, CF\&PM.

Twardus, D. B. 1982. Relationship of host bud development and western spruce budworm larval development to B.t. caused mortality. USDA Forest Service, Forest Pest Management, Pacific Northwest Region, Portland, OR, 14 pp.

Varty, I.W. and M.E. Godin. Identification of some of the factors controlling aerial spray efficacy. Information Report M-X-142, 1983. Maritimes Forest Research Centre, Fredericton, New Brunswick.

Walton, G.S. and C.J. DeMars. Empirical methods in the evaluation of estimators, a case study based on insect density and survival data. USDA Forest Service Res. Paper NE-272, 1973.

Walton, G.S. and F.B. Lewis. Spruce budworm core B.t. test - 1980, combined summary, 1982. USDA Forest Service Res. Paper NE-506, 12 pp.

Young, R.W., R.C. Luebbe, and J.W. Barry. 1977. ASCAS -- data management system for assessment of aerial spray deposits. USDA Forest Service, Forest Pest Management Methods Application Group, Rpt. No. 77-2. 
